\title{
Assessment of precautionary measures against COVID-19 in Indonesian workplaces
}

\author{
Muhammad Ricky Pratama ${ }^{1}$, Agung Supriyadi ${ }^{2}$, Nurhalina Sari ${ }^{3}$ \\ ${ }^{1}$ Department of Health Safety and Environment, PT. Sokoria Geothermal Indonesia, Indonesia \\ ${ }^{2}$ Department of Health and Safety, Drg. Suherman Medical Institute, Indonesia \\ ${ }^{3}$ Faculty of Public Health, University of Malahayati, Indonesia
}

\begin{tabular}{l} 
Article Info \\
\hline Article history: \\
Received Sep 21, 2020 \\
Revised Feb 8, 2021 \\
Accepted Mar 12, 2021 \\
\hline
\end{tabular}

Keywords:

COVID-19

Health and safety

Indonesian workplace

Precautionary measures

Workplace

\begin{abstract}
As the coronavirus disease 19 (COVID-19) pandemic spread across Indonesia, the precautionary measures have been taken by nearly all stakeholders, including industries and employers. The purpose of this study is to assess the measures took against COVID-19 pandemic in the workplaces across the country. This research involved participants from 103 different companies using a questionnaire adapted from Better Work Indonesia (BWI), occupational safety and health association (OSHA) and centers for disease control and prevention (CDC) COVID-19 guidelines. The data analysis conducted with descriptive statistics that resulted with the following key findings. Indonesian companies have taken precautionary measures against COVID-19 at their workplace. Most aspects of COVID-19 preventive measures: policy and procedure, operational aspect, health and safety, and external activities have been observed by the vast majority of the subjects. This study found that among 30 COVID-19 programs, the emergency exercise at work was the only one that had not been conducted by more than half of respondents. As the number of active cases still growing at the time this study conducted, all precautionary measures against COVID-19 shall be carried out with consistency by the company management).
\end{abstract}

This is an open access article under the CC BY-SA license.

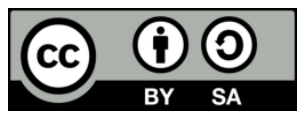

Corresponding Author:

Muhammad Ricky Pratama

Department of Health Safety and Environment

PT. Sokoria Geothermal Indonesia

Jalan Pahlawan no. 20, North Ende, Ende 86319, East Nusa Tenggara, Indonesia

Email: ricky.pratama@ksorka.com

\section{INTRODUCTION}

Indonesia reported the first case of COVID-19 on March 2, 2020 [1]. As of January 22, 2020, the fourth most populous country has reported 951,651 confirmed cases and 27,203 deaths [2]. The number of deaths in the country appears to be the highest among the Southeast Asian nations, as well as the highest number of cases in the region [3]. The government has declared the public health emergency status on March 31, 2020 marked the start of large-scale social restriction order to be implemented in the Greater Jakarta region, followed by other cities across the archipelago [4].

As the pandemic spread to all Indonesian provinces, nearly all stakeholders, including industries and organizations, have taken precautionary measures. The pandemic affects the life of 136.18 million labor force in the country [5] where many companies had to shut the operations for a while and adjusted stricter measure to prevent any occurrence of COVID-19 at their workplaces. Guidelines for preventing COVID-19 at workplace are available in national and international level. The Ministry of Manpower of Indonesia has issued specific regulations regarding labor protection against the spread of COVID-19 at the workplace and 
the business continuity amid the pandemic, namely SE Menaker No. M/3/HK.04/III/2020 [6]. Following the large-scale social restriction order being imposed, the Ministry of Industry ensured that the precautionary measures and industrial activities could be done simultaneously through its ministry-level regulation of $S E$ Menperin No. 4 Tahun 2020 [7]. At international level, the World Health Organization (WHO) has issued the guidelines to prepare workplace to combat the COVID-19 pandemic at their organizational level [8]. In addition, occupational safety and health association (OSHA) and centers for disease control and prevention (CDC) have also been released the similar guidelines [9], [10]. Based on these regulations, the new-normal practices such as working-from-home, wearing masks to all employees and visitors, as well as provision of hand washing facilities are observed by many companies.

This study aimed to examine the precautionary measures against the COVID-19 pandemic in the workplaces across the country. The study analyzed what the companies carried out on four scopes of precautionary measures: the policy and procedure, the operational aspect of the work, health and safety, and external activities.

\section{RESEARCH METHOD}

\subsection{Participants}

The population of the research was all companies in Indonesia. The samples were the companies that agreed to fill out the electronic questionnaire. The sampling technique of this research was purposive sampling. The subject of this study consists of 106 participants from 106 different companies. Nevertheless, three respondents returned the questionnaire incomplete and left the participants to 103. The companies that participants worked in are both state-owned and private companies. Furthermore, the companies are engaged in various sectors, including agriculture, mining, chemical industry, manufacture industries, consumer goods industry, property and building construction, infrastructure and transportation, financial, and trade and investment. The participants are health, safety, and environment (HSE) personnel from each company. This option was considered as COVID-19 precautionary measures would have been managed under the Health and Safety department. Some companies might appoint the control measures under its physicians, occupational doctors, or medical team. Nevertheless, the HSE personnel would be more widely available as the Indonesian regulation requires it. Health care workers were excluded from this study, considering that healthcare facilities' control measure would be much stricter than non-healthcare settings.

\subsection{Quick assessment}

The questionnaire was designed to assess the precautionary measures against COVID-19 that have been implementing on each company. The questionnaire was adapted from Better Work Indonesia (BWI)'s COVID-19 Guidance [8] with additional questions adapted from other guidelines, i.e. OSHA 3990 Guidance on Preparing Workplaces for COVID-19 [9] and CDC's COVID-19 Interim Guidance for Businesses and Employers [10]. The OSHA and CDC standards are widely used in Health and Safety field as they are based on scientific studies and partake the socio-demographic considerations. The questionnaire comprised of five sections including respondent information (employment title, region, type of industry), policy and procedure, e.g., response plan and specific procedure, the operational aspect of the work, e.g., physical distancing application and flexible worksites, health and safety, e.g., provision of face mask and hand wash facility, and external activities, e.g., teleconference with the supplier and zero visiting practices. The questionnaire was distributed using an online link to all respondents.

\subsection{Data analysis}

The questionnaire data were analyzed using IBM SPSS Statistics 22.0 [11]. The data analysis consisted mainly of descriptive statistics.

\section{RESULTS AND DISCUSSION}

Across the 106 initial respondents, $103(97.2 \%)$ of them returned the questionnaire completely. Table 1 exhibit the respondent characteristics that cover position in the company, region of the company and type of industry. Most of the respondents (54.4\%) are holding a position as an HSE Supervisor/Advisor/Engineer in their respective companies, followed HSE Manager/Superintendent/Director (29.1\%), and HSE Officer/Staff/ Inspector/Technician/Admin by $16.5 \%$. As for the region where the companies are located, most of the respondents are based in Java $(64.1 \%)$, followed by other regions, i.e., Sumatera (14.6\%), Kalimantan (10.7\%), Sulawesi (5.8\%), and Maluku and Papua (4.9\%). Regarding the type of industries, most respondents work in four industries: mining (28.2\%), infrastructures, utilities and transportation $(20.4 \%)$, property, real estate and construction $(11.7 \%)$, and various manufacture industries $(11.7 \%)$. 
Table 1. Characteristics of respondent

\begin{tabular}{|c|c|c|c|}
\hline \multirow{2}{*}{ Variables } & \multirow{2}{*}{ Categories } & \multicolumn{2}{|c|}{ Total } \\
\hline & & $\mathrm{n}=103$ & $\%$ \\
\hline \multirow[t]{3}{*}{ Position in the company } & HSE Manager/Superintendent/Director & 30 & 29.1 \\
\hline & HSE Officer/Staff/Inspector/Technician/Admin & 17 & 16.5 \\
\hline & HSE Supervisor/Advisor/Engineer & 56 & 54.4 \\
\hline \multirow[t]{6}{*}{ Region of the company } & Sumatera & 15 & 14.6 \\
\hline & Java & 66 & 64.1 \\
\hline & Kalimantan & 11 & 10.7 \\
\hline & Sulawesi & 6 & 5.8 \\
\hline & Maluku and Papua & 5 & 4.9 \\
\hline & Nusa Tenggara & 0 & 0 \\
\hline \multirow[t]{9}{*}{ Type of industry } & Agriculture (including plantations, forestry, and animal husbandry) & 2 & 1.9 \\
\hline & Mining (including oil and gas, coal, minerals, and geothermal) & 29 & 28.2 \\
\hline & Basic and chemical industry & 8 & 7.8 \\
\hline & Various manufacture industries & 12 & 11.7 \\
\hline & Consumer goods industry & 8 & 7.8 \\
\hline & Property, real estate, and building construction & 12 & 11.7 \\
\hline & Infrastructure, utilities, and transportation & 21 & 20.4 \\
\hline & Financial & 1 & 1,0 \\
\hline & Trade, services and investment & 10 & 9.7 \\
\hline
\end{tabular}

The vast majority of the subjects indicated that most policies and procedures regarding COVID-19 prevention at the workplace had been established and implemented. Table 2 shows that $97 \%$ have confirmed that their workplace has developed a specific procedure, including the emergency response plan of COVID19 cases at work. Furthermore, $95.1 \%$ of the said procedure identify the risk factor and its control. However, only $73.8 \%$ of the respondents have a specific procedure related to the receipt of the goods. A specific emergency response team and communication center for COVID-19 at the workplace is available in $91 \%$ of respondents. The similar percentage also found for companies that socialized the hotline numbers and referral hospitals for COVID-19 cases to their employees. Only $42.7 \%$ have had performed an emergency drill for COVID-19 cases. All respondents (100\%) confirmed that there had been an effort in promotion and education regarding COVID-19. They have also urged the workers not to engage in social activities that involve a large number of people.

In terms of Operations and Jobs, $95.1 \%$ of the participants implement flexible worksite and work hours to maximize the physical distancing among the workers. At the worksite itself, $90.3 \%$ of them have confirmed that there is a redesigning the workplace with the same purpose. On the lesser percentages, around seventy percent of the workplace have modified the dining area to limit to the distance for each worker. Another aspect of workplace redesigning, i.e., improving the quality of ventilation and dividing the break time into several shifts was performed by $64.1 \%$ and $66.0 \%$ respondents, respectively. All respondents have encouraged the workers to stay at home whenever they felt sick, while $82 \%$ of them confirmed that their workplace allows employees to stay home if there is a sick family member.

Subjects have shown compliance in most parts of occupational and health aspects. Based on the responses gathered, all of them have been promoting the proper handwashing practices and conducting temperature checks for workers prior to entering company premises. In addition, almost all respondents (9499\%) have confirmed that their companies have conducted certain types of health checks to their employees, provide and require the use of masks for workers, as well as visitors and vendors, encourage them to do respiratory etiquette, and regular clean up the work area with disinfectants.

Out of 103 respondents, $90.3 \%$ have advised their workers to bring their own prayer rug and subsequently remove the carpets in the praying room to avoid the viral contamination. Only $62.1 \%$ of the respondents confirmed that spraying disinfectant to the company vehicles and advice workers not to use other workers' working tools have been taken as precautionary measures against COVID-19. As for external activities aspects, respondents have shown the compliance on all of the aspects assessed: check guest travel history $(86.4 \%)$, suspend the business trip outside the city/country $(95.1 \%)$, introduce virtual meeting/teleconference instead of face-to-face meeting (97.1\%), and restrict visitor's visit (100\%).

The OSHA emphasized the importance of risk identification in workplace settings in order to determine the correct and applicable control [9]. Developing a set of policy and procedure is one of the tools that could support the employer to identify the risk factors properly. By developing such policy and procedure, the organization is expected to do the prompt action in regards with identification, as well as isolation of potentially infectious workers or areas where individuals are contracted with the COVID-19. The company could also set up its own COVID-19 risk matrices that estimate the exposure at occupational setting and susceptibility of the individual or group of workers [12]. Occupational exposures have been recorded consistently in various countries, e.g., Singapore recorded $68 \%$ of its first 25 COVID-19 as workplace-related [13]. 
Table 2. Overview of precautionary measures against COVID-19 pandemic at the workplace

\begin{tabular}{|c|c|c|c|c|}
\hline No & Questions & No & Yes & $\begin{array}{l}\text { Do not } \\
\text { know }\end{array}$ \\
\hline $\mathbf{A}$ & Policies and Procedures & & & \\
\hline 1 & $\begin{array}{l}\text { Develop a specific procedure or emergency response plan for COVID-19, } \\
\text { including if there is a suspected case of COVID-19 at work. }\end{array}$ & $3(2.9)$ & $100(97.1)$ & 0 \\
\hline 2 & $\begin{array}{l}\text { The procedure or response plan consists of how to identify areas where } \\
\text { workers can be exposed by COVID-19, risk factors (individual, work, and } \\
\text { non-work) and required control. }\end{array}$ & $5(4.9)$ & $98(95.1)$ & 0 \\
\hline 3 & $\begin{array}{l}\text { Promotion and education to the workers regarding COVID-19 using banner, } \\
\text { poster and other media. }\end{array}$ & 0 & $103(100)$ & 0 \\
\hline 4 & $\begin{array}{l}\text { Create a task force or emergency response team COVID-19 at work to } \\
\text { monitor the updated information of COVID-19 from the government and } \\
\text { related officials. }\end{array}$ & $7(6.8)$ & $94(91.3)$ & $2(1.9)$ \\
\hline 5 & $\begin{array}{l}\text { Provide a communication and information centre at workplace which } \\
\text { authorized to issue official announcements and to act as Q and A centre } \\
\text { regarding COVID-19 control. }\end{array}$ & $7(6.8)$ & $94(91.3)$ & $2(1.9)$ \\
\hline 6 & $\begin{array}{l}\text { The company urges employees not to engage in activities that involve large } \\
\text { numbers of people (social gathering and recitation) during off work. }\end{array}$ & $2(1.9)$ & $100(97.1)$ & $1(1.0)$ \\
\hline 7 & $\begin{array}{l}\text { Perform emergency drill/simulations with scenarios related to handling } \\
\text { COVID-19 cases at work. }\end{array}$ & $56(53.3)$ & $44(42.7)$ & $3(2.9)$ \\
\hline 8 & $\begin{array}{l}\text { Socializing hot line numbers and referral hospitals for COVID-19 cases to the } \\
\text { employees. }\end{array}$ & $7(6.8)$ & $94(91.3)$ & $2(1.9)$ \\
\hline 9 & $\begin{array}{l}\text { Make procedures related to receipt of goods, including goods from abroad } \\
\text { (endemic areas). }\end{array}$ & $22(21.3)$ & $76(73.8)$ & $5(4.9)$ \\
\hline B & Operations and Jobs & & & \\
\hline 10 & $\begin{array}{l}\text { Implement flexible worksites (work from home, telecommuting) or flexible } \\
\text { workhours (setting shifts), to maximize physical distancing among workers. }\end{array}$ & $5(4.9)$ & $98(95.1)$ & 0 \\
\hline 11 & Design work areas with the principle of physical distancing if possible. & $9(8.7)$ & $93(90.3)$ & $1(1.0)$ \\
\hline 12 & $\begin{array}{l}\text { Divide the break time into several shifts to avoid the large number of workers } \\
\text { gathered at the same time. }\end{array}$ & $31(30.2)$ & $68(66.0)$ & $4(3.8)$ \\
\hline 13 & $\begin{array}{l}\text { Modify the dining area into an individual space by providing a barrier or } \\
\text { providing physical distance for each worker. }\end{array}$ & $25(24.3)$ & $75(72.8)$ & $3(2.9)$ \\
\hline 14 & Encourage workers to stay at home if they are sick. & $3(2.9)$ & $100(97.1)$ & 0 \\
\hline 15 & $\begin{array}{l}\text { There is a policy to allow workers to stay at home if there are sick family } \\
\text { members. }\end{array}$ & $13(12.6)$ & $84(81.6)$ & $6(5.8)$ \\
\hline 16 & $\begin{array}{l}\text { Improve the quality of ventilation at workplace including in the operational } \\
\text { vehicles. }\end{array}$ & $23(22.3)$ & $66(64.1)$ & $14(13.6)$ \\
\hline $\mathbf{C}$ & Occupational Safety and Health & & & \\
\hline 17 & $\begin{array}{l}\text { Conduct periodic, special health checks and health checks before work } \\
\text { placement to all workers. }\end{array}$ & $3(2.9)$ & $99(96.1)$ & $1(1.0)$ \\
\hline 18 & $\begin{array}{l}\text { Promote proper handwashing practices and provide soap and hand washing } \\
\text { facilities with min. } 60 \% \text { alcohol at work. }\end{array}$ & 0 & $103(100)$ & 0 \\
\hline 19 & $\begin{array}{l}\text { Conduct temperature checks for workers before entering the company } \\
\text { premises. }\end{array}$ & 0 & $103(100)$ & 0 \\
\hline 20 & Provide and require the use of masks for workers in the company premises. & $1(1.0)$ & $102(99.0)$ & 0 \\
\hline 21 & $\begin{array}{l}\text { Require the use of masks for contractors/guests/vendors who work/visit the } \\
\text { company. }\end{array}$ & $4(3.9)$ & $97(94.2)$ & $2(1.9)$ \\
\hline 22 & $\begin{array}{l}\text { Encourage workers to do respiratory etiquette i.e., to close a cough and } \\
\text { sneeze with an inner arm or use disposable tissue. }\end{array}$ & $1(1.0)$ & $102(99.0)$ & 0 \\
\hline 23 & $\begin{array}{l}\text { Clean up using disinfectants on the areas that often touched by employees } \\
\text { e.g., door handle, lift, and handrail. }\end{array}$ & $2(1.9)$ & $99(96.2)$ & $2(1.9)$ \\
\hline 24 & Spray disinfectants on the vehicles entering and leaving the workplace. & $34(33.0)$ & $64(62.1)$ & $5(4.9)$ \\
\hline 25 & $\begin{array}{l}\text { Do not use the shared carpets in the praying room and advice workers to } \\
\text { bring their own prayer rug instead. }\end{array}$ & $7(6.8)$ & $93(90.3)$ & $3(2.9)$ \\
\hline 26 & Advice worker to not use other employees' working tools. & $34(33.0)$ & $64(62.1)$ & $5(4.9)$ \\
\hline D & External Activity & & & \\
\hline 27 & $\begin{array}{l}\text { Change the meeting system with suppliers/customers from face to face to a } \\
\text { virtual meeting/teleconference. }\end{array}$ & $3(2.9)$ & $100(97.1)$ & 0 \\
\hline 28 & Suspend any local or international business travel. & $5(4.9)$ & $98(95.1)$ & 0 \\
\hline 29 & $\begin{array}{l}\text { Restrict visitor visits from outside, including not allowing sick workers, } \\
\text { guests and visitors (i.e., fever and flu) to enter the company area. }\end{array}$ & 0 & $103(100)$ & 0 \\
\hline 30 & Check guest travel history through passport/interview. & $10(9.7)$ & $89(86.4)$ & $4(3.9)$ \\
\hline
\end{tabular}

Almost all participants are already developed the specific COVID-19 policy and procedure. A set of internal protocols would enable HSE to identify the risk factors, whether it was an individual, occupational, or non-occupational factor. The procedure has also become guidance of required mitigation plan that need to be implemented to prevent the occurrence of the COVID-19 at work. While it is a part of the daily task for HSE to ensure that health and safety procedures are implemented and complied, developing a new standard in a relatively short period is a challenging thing to do. It is even more challenging as the COVID-19 
protocols are dynamic with new requirements are expected to be incorporated along with the current finding of COVID-19 natures and characteristics. HSE is expected to be more up to date to the latest standard first before both the management and workers.

Furthermore, the procedures shall also cover the company's roles in preparedness and responses when the confirmed cases of COVID-19 occur in the company. During the times of uncertainty like this pandemic, companies are urged to think in regards with their business continuity plan. The contingency plan shall emphasize various things, including encouragement of teleworking, medical screening, follow-up the cases, training and information, and return-to-work assistance [14]. The plan may also forecast other problem that may emerge as a result of a pandemic such as absenteeism, workforce reduction, and interrupted supply chain [15]. This study confirmed that most of the subjects followed the recommendation to implement the COVID-19 contingency plan by creating the emergency response team. The team lead the execution of actions that have written on the plan. However, we found that less than half of the respondents have not conducted any form of emergency preparedness exercise. Despite the benefits, lack of interest and perceived the exercise as stressful or unpleasant might be responsible for this finding [15].

Performing an emergency exercise is a common practice in HSE, and many companies make it compulsory to conduct various possible scenarios such as fire, natural disasters, public health outbreak, and civil unrest. The exercise could be either discussion-based (i.e., table-top, workshop) or operation-based (i.e., drill, field exercise) [16], or even using current technologies such as virtual reality (VR) [17]. A review study concluded that the emergency exercise is effective at improving the knowledge, related policies and procedures, as well as boost the confidence, competence, perception and understanding of emergency activities [18]. By performing the exercise, companies could make an evaluation to get the lesson learned then improve the existing emergency plan. WHO has released various COVID-19 simulation exercise packages [19], whereas the UN provides an example of their own table-top scenario that could be adapted at the other organizational setting, including workplace [20].

The emergency response team shall also have a role in managing communication of COVID-19. The roles are including to disseminate the latest issues, answer any concern raised regarding the pandemic, and inform the hotline numbers and referral medical facilities for COVID-19 cases. This study confirmed that over $90 \%$ of respondents had implemented these roles at their companies. Communication is indeed one of the most important aspects of how employers handle this crisis while the business still needs to be run. Communicating the risk effectively is an important course to manage info emic [21]. It has to do with developing the communication strategies, establishing communication with the public health authority and referral medical facilities, and how to communicate the risk of COVID-19 and its preventive measures to the workers. It is important for employers to communicate updated cases under their authority. Nevertheless, employers should avoid disclosing the details of personal information that could lead to stigmatization and privacy violation [22].

Conveying the important information to the workers is also a part of the promotion and education of health behavior. Risk awareness is the key to hinder and slow down the spread of COVID-19 transmission [21]. The essence of health promotion is enabling the workers to enhance their control over their health status and its determinants [23]. In this study, we found that the effort has been performed using various communication materials, e.g., banner, poster, and other available media. We examined further this issue by confirming whether several key topics were delivered using those materials. The responses were all respondents have had promoted the proper handwashing practices, $99 \%$ of them have also encouraged the workers to do respiratory etiquette, $97 \%$ have advised workers stay at home if they are sick, and $90 \%$ have informed the Muslim workers to bring their own prayer rug. Only $62 \%$ have advised workers to not use other employees' working tools.

In addition, the study participants also have promoted the urgency of social distancing practices. Around $97 \%$ have encouraged workers to avoid large gathering to minimize contacts with other people. Multiple studies [24]-[27] have demonstrated the effectiveness of physical distancing to contain the viral transmission, including one systematic review [28] that reported the protection against the risk of infection might increase by double (RR 2.02, 95\% CI 1.08-3.76) for every one-meter of physical distancing lengthen. The study also emphasized the safe distancing above $2 \mathrm{~m}$ is considered as highly effective. The practice of social distancing is also performed by $90 \%$ subjects by redesigning the company premises with the principle of physical distancing wherever possible. Whereas we did not ask specifically the distance enforced at respective companies, the WHO advised the minimum distance of 1 meter to be applied at the workplace including on the meeting or event [24], while other countries put different minimum distances from $1.5 \mathrm{~m}$ to $2 \mathrm{~m}$ on public setting [29]. Safe distancing shall be enforced on the workplaces where the interaction between employees and customers is inevitable, such as banks, hotels, and retails stores [30]. We also noted that $97 \%$ of subjects had implemented the virtual meeting with their customers or suppliers instead of a face-to-face meeting. 
COVID-19 has created some radical changes in how people work. Aside from the physical distancing, redesigning the workplace also pertain in how companies implement flexible worksite and flexible work hours. Any form of flexible worksites, e.g., working from home, telecommuting or flexible workhours, e.g., working with the shift, shorten work hours are confirmed by $95 \%$ study subjects. We examined further practices of redesigning the workplace that has had implemented by them. Around twothirds of subjects have divided the break time into several shifts to maximize the safe distancing among employees. Four studies have confirmed that COVID-19 increased the preference for dining facilities in a more private arrangement [31]. Almost three-quarter of them has modified the dining area by providing a barrier or enforcing the physical distancing in that area. The employer should be very concerned as the use of a face mask cannot be fully enforced while the employees are eating or drinking. A study that investigated an outbreak at the Chinese restaurant highlighted the increase of distance between tables and ventilation improvement as the key to preventing the spread at the common area-setting like restaurant [32].

In regards with the ventilation, $64 \%$ of respondents have had some improvements in the ventilation at work. Proper ventilation is a part of engineering controls. Its mechanical application, i.e., local exhaust ventilation (LEV) and Heating, ventilating and air conditioning (HVAC) are very important aspects of Indoor air quality (IAQ) by displacing and diluting the airborne contaminant. While it is generally considered that the current pandemics spread through droplets, some argued that it is highly likely an airborne transmission like its predecessor, SARS-CoV-1 [33]. Companies need to ensure its existing building engineering controls function a sufficient and effective manner. Particulates filtration, air disinfectant and minimizing air recirculation are other applicable controls that could be carried out [34].

We managed to ask respondents regarding the application of cleaning and disinfection. WHO highlighted the importance of disinfection practices to lower the risk of contamination of COVID-19 in the occupational environment [35]. Other studies confirmed the effectiveness of disinfection to halt the spread of SARS-CoV-2 [36], [37]. Disinfection shall be applied on the high touch surfaces such as door handles, dining area, bathroom surfaces, water taps, and computer keyboards shall. Almost all (96\%) subjects had performed the cleaning and disinfection, while only $62 \%$ had done that on the operational vehicles. WHO do not recommend the large-scale spraying in open spaces areas as it deemed as ineffective [35]. Nevertheless, the disinfection of operational vehicle could be carried out on its high-touch surfaces like door panel, handle, and switch. All subjects also reported that they had provided the hand hygiene facilities, i.e., handwashing facilities including soap and/or sanitizer with at least $60 \%$ alcohol.

This study demonstrated that the precautions related to health examination were taken adequately. Conducting health check (pre-job, periodic, and additional) was also taken by the vast majority of respondents-96\%. At the time of COVID-19 pandemic, a large-scale medical screening, i.e., swab testing is considered as the best strategy to prevent any contagious person from entering the workplace [38]. This strategy would be more reasonable in the case of returning employees, as many countries have begun to reopen the economy. As such, the guideline of return to work is needed. In addition to that, the daily check of employees' health using a temperature check is recommended [39], and the repeated measurement is necessary [40]. WHO set the body temperature of $37.3^{\circ} \mathrm{C}$ or higher as an indicator of low-grade fever and mild cough in the context of preventing COVID-19 [30]. All respondents confirmed that they had conducted the temperature check for workers prior to entering the workplace.

Personal protective equipment (PPE) is often considered as the last resort to protect workers from hazards, yet it is the most critical one. Respiratory protective equipment became the most significant PPE as the primary routes of entry of COVID-19 are through respiratory tracts. NIOSH-certified N95 and EU's FFP2 respirators are among the recommended face mask. Nevertheless, considering the limitation of stock and distribution, those masks are prioritized for the healthcare workers who have been at a higher risk of COVID-19 transmission [41]. Later, WHO advised the use of a non-medical mask that made from cloth fabric for specific working conditions where physical distancing cannot be achieved, or employees are in close contact with others [42]. Our study reported the compliance with the use of masks at the company were 99\% for employees and $94 \%$ for short-timed visitors/vendors/contractors. We did not ask further the type of mask being used at their workplace. Even so, one meta-analysis [28] suggested that the use of face mask was protective with no difference in effectiveness between the healthcare setting (N95 mask) and non-healthcare setting (cloth mask).

COVID-19 pandemic has restricted the people's movement around the globe with many travel restrictions have been imposed. We found that $95 \%$ of our study subjects had suspended local or international business travel to minimize the risk of coronavirus infection. Travel bans were highly effective to delay the widespread coronavirus transmission with some modelling estimated the reduced case up to 79\% [43] and $86 \%$ [44]. As a place where the access is normally controlled, it is not surprising that employers would put even stricter access control into its company premises. All study participants reported that there is a restriction to visitors, particularly to whom have shown the fever and flu-like symptoms. Around $86 \%$ of 
them have a further examination on the guest travel history through passport checking or interview, while a third quarter of total respondents have developed a specific procedure that related to receipt of goods.

\subsection{Study limitation}

Our study used a cross-sectional analysis which notes some disadvantages, particularly in its reliability. As a self-reported data, there was no further investigation conducted to each answer given. The 30 items of the questionnaire were based on various sources. Nevertheless, the validity of them remains to be subject to an examination. Some biases might have been affected by the reliability of this study. We only invited companies that hired HSE personnel which would have better COVID-19 control measures compared to informal sectors or small-medium enterprises. Respondent bias might have occurred as the respondents exaggerated the actions taken against COVID-19 at their companies.

\section{CONCLUSION}

Indonesian companies had taken precautionary measures against COVID-19 at their workplace. Generally, all aspects of COVID-19 prevention, including policy and procedure, operational aspect, health and safety, and external activities, have been implemented. The present study also noted that COVID-19 emergency exercise at work had not been conducted by most companies. Additional studies are needed to address this concern. Considering the number of COVID-19 cases that keep growing, the precautionary measures shall be carried out with consistency. Management shall monitor the latest update of the current pandemic to know whether changes or additional measures need to be taken.

\section{REFERENCES}

[1] World Health Organization, "Coronavirus Disease (COVID-19) Situation Reports," 2020. [Online]. Available: https://www.who.int/emergencies/diseases/novel-coronavirus-2019/situation-reports/.

[2] World Health Organization, "Indonesia: WHO Coronavirus Disease (COVID-19) Dashboard | WHO Coronavirus Disease (COVID-19) Dashboard," 2021. [Online]. Available: https://covid19.who.int/region/searo/country/id.

[3] Center for Strategic And International Studies, 'Southeast Asia Covid-19 Tracker | Center for Strategic and International Studies', 2020. [Online]. Available: https://www.csis.org/programs/southeast-asia-program/southeastasia-covid-19-tracker-0.

[4] R. Djalante et al., "Review and analysis of current responses to COVID-19 in Indonesia: Period of January to March 2020," Progress Disaster Science, vol. 6, p. 100091, 2020.

[5] Statistics Indonesia, "Population 15 Years and Over Who Worked by by Main Industry 1986 - 2019," [Online]. Available: https://www.bps.go.id/dynamictable/2020/02/19/1775/penduduk-berumur-15-tahun-ke-atas-menurutjenis-kegiatan-tahun-1986---2019.html.

[6] Ministry of Manpower of Republic Indonesia, "Ministry of Manpower Issues Letter of Notification Regarding Labor Protection and Business Continuity Related to Covid-19", 2020. [Online]. Available: https://kemnaker.go.id/news/detail/menaker-terbitkan-surat-edaran-tentang-pelindungan-buruh-dan-kelangsunganusaha-terkait-covid-19.

[7] Ministry of Industry of Republic of Indonesia, "The Ministry of Industry Ensures Industrial Activities and Covid19 Prevention Protocols Can Go Together, 2020." [Online]. Available: https://kemenperin.go.id/artikel/21679/Kemenperin-Pastikan-Kegiatan-Industri-dan-Protokol-Pencegahan-Covid19-Dapat-Berjalan-Beriringan.

[8] Better Work Indonesia, "Compilation of Guidelines on Covid-19 Transmission, Prevention and Management and the Best Practices in the Workplace," 2020.

[9] OSHA, "Guidance on Preparing Workplaces for COVID-19", 2020.

[10] CDC, "COVID-19 Guidance: Businesses and Employers|CDC." [Online]. Available: https://www.cdc.gov/coronavirus/2019-ncov/community/guidance-business-response.html.

[11] IBM, "SPSS Software/IBM'. [Online]. Available: https://www.ibm.com/analytics/spss-statistics-software. [Accessed: 23-Jan-2021].

[12] R. Agius, 'Covid-19 and Health at Work', Occupational Medicine, vol. 70, no. 5. Oxford University Press, pp. 349351, 01-Jul-2020.

[13] D. Koh, "Occupational risks for COVID-19 infection," Occupational Medicine, vol. 70, no. 1. Oxford University Press, pp. 3-5, 12-Mar-2020.

[14] M. Fadel, J. Salomon, and A. Descatha, "Coronavirus outbreak: the role of companies in preparedness and responses," The Lancet Public Health, vol. 5, no. 4, p. e193, 2020.

[15] K. J. Collins and T. J. Draycott, "Skills and drills: Are they worth the effort?," Obstetrics, Gynaecology and Reproductive Medicine, vol. 25, no. 12. pp. 372-374, 2015.

[16] European Centre for Disease Prevention and Control, "Handbook on simulation exercises in EU public health settings," 2014. [Online]. Available: https://www.ecdc.europa.eu/en/publications-data/handbook-simulationexercises-eu-public-health-settings.

[17] N.-F. Li and Z. Xiao, "Paper-A fire drill training system based on vr and kinect somatosensory technologies a fire drill training system based on VR and kinect somatosensory technologies," International Journal of Online and 
Biomedical Engineering, vol. 14, no. 4, pp. 163-176, 2018.

[18] E. Skryabina, P. Riley, G. Reedy, and R. Amlôt, "A scoping review of evaluation methods for health emergency preparedness exercises," American journal of disaster medicine, vol. 13, no. 2, pp. 107-127, 2018.

[19] WHO, "Simulation exercise," 2020. [Online]. Available: https://www.who.int/emergencies/diseases/novelcoronavirus-2019/training/simulation-exercise.

[20] UN, "COVID-19 Pandemic Tabletop Exercise," 2020. [Online]. Available: https://www.un.org/sites/un2.un.org/files/coronavirus_ttxscenario_2020-03-11.pdf.

[21] R. Chatterjee et al., "COVID-19 Risk Assessment Tool: Dual application of risk communication and risk governance," Progress in Disaster Science, vol. 7, p. 100109, 2020.

[22] M. Shabani, T. Goffin, and H. Mertes, "Reporting, recording, and communication of COVID-19 cases in workplace: Data protection as a moving target," Journal of Law and the Biosciences, vol. 7, no. 1, pp. 1-5, 2020.

[23] S. Van den Broucke, "Why health promotion matters to the COVID-19 pandemic, and vice versa', Health Promotion International, vol. 35, no. 2, pp. 181-186, 2020.

[24] WHO, "Overview of public health and social measures in the context of COVID-19," World Health Organization no. May, pp. 1-8, 2020.

[25] M. Bielecki et al., "Social distancing alters the clinical course of COVID-19 in young adults: a comparative cohort study," Clinical Infectious Diseases, 2020, doi: 10.1093/cid/ciaa889.

[26] A. D. Wiese, J. Everson and C. G. Grijalva, "Social distancing measures: evidence of interruption of seasonal influenza activity and early lessons of the SARS-CoV-2 pandemic," Clinical Infectious Diseases, 2020, doi: 10.1093/cid/ciaa834.

[27] K. J. Bourassa, D. A. Sbarra, A. Caspi, and T. E. Moffitt, "Social Distancing as a Health Behavior: County-Level Movement in the United States during the COVID-19 Pandemic Is Associated with Conventional Health Behaviors," Annals of Behavioral Medicine, vol. 54, no. 8, pp. 548-556, 2020.

[28] D. K. Chu et al., "Physical distancing, face masks, and eye protection to prevent person-to-person transmission of SARS-CoV-2 and COVID-19: a systematic review and meta-analysis," The Lancet, vol. 395, no. 10242, pp. 19731987, 2020

[29] N. Williams, "Social Distancing in the Covid-19 Pandemic," Occupational Medicine, vol. 70, no. 5, p. 305, 2020.

[30] M. Belingheri, M. E. Paladino and M. A. Riva, "COVID-19: Health prevention and control in non-healthcare settings', Occupational Medicine, vol. 70, no. 2, pp. 82-83, 2020.

[31] J. Kim and J. C. Lee, "Effects of COVID-19 on preferences for private dining facilities in restaurants," Journal of Hospitality and Tourism Management, vol. 45, pp. 67-70, 2020, doi: 10.1016/j.jhtm.2020.07.008

[32] J. Lu et al., "COVID-19 Outbreak Associated with Air Conditioning in Restaurant, Guangzhou, China, 2020," Emerging Infectious Diseases, vol. 26, no. 7, pp. 1628-1631, 2020.

[33] L. Morawska and J. Cao, "Airborne transmission of SARS-CoV-2: The world should face the reality," Environment International, vol. 139, p. 105730, 2020.

[34] L. Morawska et al., "How can airborne transmission of COVID-19 indoors be minimised?," Environment International, vol. 142, p. 105832, 2020.

[35] WHO, "Cleaning and disinfection of environmental surfaces in the context of COVID-19," 2020. [Online]. Available: https://www.who.int/publications/i/item/cleaning-and-disinfection-of-environmental-surfaces-inthecontext-of-covid-19.

[36] M. H. Al-Sayah, "Chemical disinfectants of COVID-19: An overview," Journal of Water and Health, vol. 18, no. 5, pp. 843-848, 2020

[37] A. Roy, S. P. Parida, and V. Bhatia, "Role of disinfection and hand hygiene: a COVID-19 perspective," International Journal of Community Medicine and Public Health, vol. 7, no. 7, p. 2845, 2020.

[38] J. C. Rueda-Garrido et al., "Return to work guidelines for the COVID-19 pandemic', Occupational Medicine, vol.70, no. 5, pp. 300-305, 2020, doi: https://doi.org/10.1093/occmed/kqaa099.

[39] B. Gohar, M. Larivière, and B. Nowrouzi-Kia, "Sickness absence in healthcare workers during the COVID-19 pandemic," Occupational Medicine, vol. 70, no. 5, pp. 338-341, 2020.

[40] S. H. Hsiao, T. C. Chen and H. C. Chien, "Measurement of body temperature to prevent pandemic COVID-19 in hospitals in Taiwan: repeated measurement is necessary," Journal of Hospital Infection, vol. 105, no. 2, pp. 360 $361,2020$.

[41] A. Spinazzè, A. Cattaneo, and D. M. Cavallo, "COVID-19 Outbreak in Italy: Protecting Worker Health and the Response of the Italian Industrial Hygienists Association," Annals of Work Exposures and Health, vol. 64, no. 6. pp. 559-564, 2020.

[42] WHO, "Advice on the use of masks in the context of COVID-19," in WHO, no. April, pp. 1-5, 2020.

[43] A. Adekunle, M. Meehan, D. Rojas-Alvarez, J. Trauer and E. McBryde, "Delaying the COVID-19 epidemic in Australia: evaluating the effectiveness of international travel bans," Australian and New Zealand Journal Public Health, vol. 44, no. 4, pp. 257-259, 2020.

[44] V. Costantino, D. J. Heslop, and C. R. MacIntyre, "The effectiveness of full and partial travel bans against COVID19 spread in Australia for travellers from China during and after the epidemic peak in China," Journal Travel Medicine, vol. 27, no. 5, 2020. 